\title{
KULTUREMY POLSKIE - PUNKTY WIDZENIA, TECHNIKI ICH WYDOBYWANIA I NEGOCJOWANIA. STOSOWANIE PERSPEKTYWY ETNOLINGWISTYCZNEJ W GLOTTODYDAKTYCE POLONISTYCZNEJ
}

\begin{abstract}
Słowa kluczowe: kulturem, punkty widzenia, wydobywanie, typowanie, negocjowanie, etnolingwistyka, glottodydaktyka polonistyczna, nauczanie języka polskiego jako obcego

Streszczenie. W artykule zachęca się do stosowania perspektywy i metodologii etnolingwistycznej w glottodydaktyce języka polskiego. W części wprowadzającej omawiane jest, z wykorzystaniem światowej i polskiej literatury, pojęcie kulturemu - jednostki kultury należącej do danego systemu kulturowego i istotne dla jej zrozumienia. Konieczność włączania kultury do nauczania języka polskiego jako języka obcego jest sprawą bezdyskusyjną. Sposoby wydobywania (typowania) kulturemów z ogromnej przestrzeni danej kultury wydają się natomiast mniej oczywiste. Kto jest „upoważniony” do ich typowania - tylko przedstawiciel rodzimej kultury czy także zewnętrzny obserwator? Czy można wydobyć kulturemy w wyniku procesu negocjacji? W artykule przedstawiono techniki ich wyboru i negocjowania z wykorzystaniem perspektywy wewnętrznej i zewnętrznej, a także opisano propozycje wykorzystania tej metodologii w praktyce nauczania języka polskiego jako obcego.
\end{abstract}

\section{ROZWAŻANIA TERMINOLOGICZNE - DEFINIOWANIE KULTUREMU}

Kulturem jest pojęciem, z którym humanistyczne środowisko naukowe reprezentujące takie obszary językoznawstwa, jak: etnolingwistyka, lingwistyka kulturowa, językoznawstwo korpusowe a także glottodydaktyka polonistyczna, jest - jak sądzę - dobrze zaznajomione. Kulturem to, ujmując zagadnienie w naj-

* grazyna.zarzycka@uni.lodz.pl, Uniwersytet Lódzki, Wydział Filologiczny, Zakład Lingwistyki Stosowanej i Kulturowej, Instytut Filologii Polskiej i Logopedii, ul. Pomorska 171/173, 90-236 Łódź. 
większym skrócie, znaczący element kultury (bogaty w znaczenia, stąd pełni funkcję jej interpretanta), który może być egzemplifikowany przez zachowanie językowe (słowa, zdania, teksty) i niejęzykowe (zachowania społeczne, parawerbalne - jak: mimika, gesty i zachowania proksemiczne). Przeważa jednak pogląd, że kulturemy to językowe obrazy znaczeń kulturowych reprezentowane najczęściej przez jednostki leksykalne: nazwy własne (szczególnie interesujące jako jednostki ,ttumaczące” kulturę są te posiadające znaczenie wtórne, metaforyczne), etnonimy, egzotyzmy, ksenizmy (tzw. leksyka bezekwiwalentna), słowa klucze (zob. Wierzbicka 2007; Łaziński [dostęp: 15.10.2018], a także m.in. tzw. słowa sztandarowe (Pisarek 2003), skrypty kulturowe (Wierzbicka 1999), symbole kolektywne (Fleischer 2003), stereotypy językowe (Bartmiński 2007), leksyka realioznawcza (Nagórko 2004, za: Burkhardt 2008). Badacze są zgodni co do tego, że kulturem jest (powinien być) elementem żywego języka - cechuje go witalność, mieści się w słownictwie o dość dużej frekwencji (Rak 2015, s. 11-12); choć mnie samej nie wydaje się niestosowne, by szukać kulturemów w tekstach dawnych.

Autorstwo terminu przypisuje się E. Oksaar (1998), a do językoznawstwa polskiego wprowadziła go Hanna Burkhardt (2008) z Uniwersytetu Humboldtów w Berlinie. Pojęcie to, wraz z innymi pokrewnymi pojęciami, zostało omówione przez Annę Dąbrowską [dostęp: 15.09.2018] w znanym i dostępnym w sieci artykule. Autorka poświęca w nim sporo miejsca koncepcjom lingwistycznokulturowym wprowadzonym podczas polonistycznych dyskusji glottodydaktycznych, jak: pojęcie lingwakultury (Agar 1994; Zarzycka 2004, 2008), leksykultury (m.in. Galisson 1999; Ligara 2009), egzotyzmu (Przybylska 2005).

Kulturem jako termin wkroczył niedawno - za sprawą badań Macieja Raka (2015) z Uniwersytetu Jagiellońskiego - do dialektologii, dowodząc jej zbliżenia $\mathrm{z}$ etnolingwistyką ${ }^{1}$. Monografia M. Raka została opatrzona Wprowadzeniem i rozdziałem teoretycznym, w których szeroko omówiono literaturę przedmiotu dotyczącą kulturemu, jak też zaprezentowano jego definicje i koncepcje związane z ich wydobywaniem (wg Raka: typowaniem); pojawiły się tu prace wszystkich autorów wspomnianych wyżej, w tym również koncepcje wprowadzone na grunt polski przez zorientowanych w stronę lingwistyki kulturowej glottodydaktyków polonistycznych.

M. Rak uznał kulturem za hiperonim takich pojęć jak: egzotyzm, ksenizm, słowo klucz i innych pokrewnych. Przyjął też, za A. Nagórko (m.in. 1994, 2004), rozumienie kulturemów jako jednostek etnolingwistycznych, słów kluczy, które reprezentowane są przez pojedyncze leksemy o bogatej treści, dzięki czemu „można zrozumieć specyfikę danej społeczności narodowej, etnicznej lub regionalnej”

${ }^{1}$ Etnolingwistyka lubelska miała swój początek w dialektologii, następnie w dużym stopniu zautonomizowała się, by z kolei odcisnąc się w polskiej dialektologii, zasilając ją terminologią i koncepcjami metodologicznymi. 
(Rak 2015, s. 13). W drugiej części tej wypowiedzi określił więc podstawową funkcję kulturemów. W innym miejscu pisze, z czym się zgadzam: „kulturemy służą (samo)identyfikacji konkretnej społeczności” (Rak 2015, s. 14).

\section{WYDOBYWANIE KULTUREMÓW - METODOLOGIA}

Ważna dla naszych dalszych rozważań jest przyjęta przez M. Raka owa podwójna perspektywa typowania kulturemów: (SAMO)IDENTYFIKACJA - autor przeprowadził badania wśród trzech pokoleń Podhalan, jak też wśród osób (również reprezentujących trzy pokolenia) niezwiązanych z tym regionem, co pozwoliło mu wyodrębnić autostereotypy podhalańskie, wyobrażenia mieszkańców Podhala o sobie samych i o ich świecie, jak też heterostereotypy oraz opinie obcych - „ceprów”2. Zadaniem badacza było określenie i zinterpretowanie różnic między owymi spojrzeniami. Działania interpretacyjne można, jak sądzę, uznać za kolejną - trzecią - perspektywę $e^{3}$.

Z powyższych rozważań wynika, że kulturem jest pojęciem negocjowalnym. Swoi i obcy mogą mieć całkiem lub nieco inne wyobrażenia o tym, co - i do jakiego stopnia - jest elementem znaczącym dla danej społeczności. Odnosi się to także do przedstawicieli różnych pokoleń w obrębie tej samej grupy. M. Rak znalazł kompromisowe rozwiązanie - skupił się na opisie uniwersalnych kulturemów podhalańskich.

Metodologia zastosowana przez M. Raka jest charakterystyczna dla badań etnolingwistycznych/lingwistycznokulturowych ukierunkowanych na wydobywanie i opis językowych obrazów świata (JOS). Polega na studiowaniu różnorodnych źródeł ustnych i pisanych tworzonych przez reprezentantów danej wspólnoty (perspektywa wewnętrzna / wewnętrzny (swojski) punkt widzenia) - tu: mieszkańców danego regionu czy wspólnoty (od źródeł folklorystycznych po teksty współczesne). Ważne są także źródła ustne i pisane na temat danego regionu (wypowiedzi ustne, pamiętniki, dzienniki podróży, teksty medialne - blogi, fora internetowe, literackie) tworzone przez osoby spoza regionu (perspektywa zewnętrzna / zewnętrzny punkt widzenia). Badania koncentrują się oczywiście także na danych ze słowników folklorystycznych i ogólnych. Poszukiwane są i badane frazemy z użyciem określonych jednostek leksykalnych i sposoby interpretowania danych pojęć czy zjawisk kulturowojęzykowych.

${ }^{2}$ Maciej Rak w pierwszym przypisie swojego Wprowadzenia (Rak 2005, s. 7) odnosi się także do dialektologicznej monografii Jolanty Tambor (2008): Mowa Górnoślazaków. Autorka, podobnie jak Rak w odniesieniu do Podhala, tylko kilka lat wcześniej, przebadała symbole śląskości, śląskie hasła, śląskie słowa klucze, stosując perspektywę swoich - Ślązaków i obcych - goroli, a więc wydobywając śląskie autostereotypy i heterostereotypy.

${ }^{3}$ Badanie jakichś zjawisk z zastosowaniem różnych punktów widzenia jest przyjęte m.in. w socjologii (badanie stereotypów) czy w medioznawstwie, a także w psychologii i psychoterapii. 
Ważnym sposobem pozyskiwania kulturemów są badania ankietowe, rozmowy, wywiady (por. z metodą SAT opracowaną przez etnolingwistów lubelskich) - w przypadku badań Raka było to postawienie pytań otwartych: co według ciebie jest: 1) najważniejsze; 2) charakterystyczne dla prawdziwego Górala?; 3) jakie gwarowe słowa są charakterystyczne dla prawdziwego Górala? Interpretując wyniki swoich badań, Rak przypisał wydobytym wyrażeniom określone aspekty: bytowy, etyczny, fizykalny, ideologiczny, kulturowy, lokatywny, psychiczny, psychospołeczny, religijny, społeczny, następnie stworzył listę 34 najbardziej wyrazistych kulturemów, grupując je według pytań: 1. Kim jestem? Kim nie chciałbym być? górál, gazda, baca, juhas, zbójnik, ksiondz, pán, ceper; 2. Gdzie jestem? Gdzie mieszkam? Podhále, góry, Giewont, hála; 3. Co jest dla mnie ważne? Pámbócek, Pániezus, Gaździná Podhála, krzýz, śleboda, honór, robota, ziym, dudki; 4. Czego się obawiam? biyda, głód; 5. Co mnie odróżnia od innych? Co jest dla mnie charakterystyczne? gwara, muzýka, śpiywanie, tániec, ubranie, portki, ciupaga, moskál, oscypek, gorzátka, owca (Rak 2005, s. 30-31). Eksplikując kulturemy podhalańskie, autor zastosował formułę definicji kognitywnej, opracowaną przez zespół J. Bartmińskiego (1988).

\section{WYKORZYSTANIE ETNOLINGWISTYKI W GLOTTODYDAKTYCE POLONISTYCZNEJ}

Tezy i postulaty wypływające z tego, co powyżej i z własnych doświadczeń glottodydaktycznych pragnę przedstawić w postaci kilku stwierdzeń:

- Kulturemy są stałymi elementami nauczania i poznawania języka obcego i języka polskiego jako obcego (JPJO). Pojawiają się na każdym etapie nauczania i poznawania JPJO. Nawet jeśli nauczyciel lub uczący się nie skupiają się na kulturze języka docelowego, kulturemy (polskie uniwersalia kulturowe lub kulturemy związane $\mathrm{z}$ regionem) przenikają naturalnie do języka - wraz z powiększaniem się leksykonu uczących się, dzięki obserwacjom realiów (por. nazwy ludzi, ulic, produktów, skrypty kulturowe, etykieta) i uczestnictwu w życiu danej wspólnoty.

- Kulturemy, jako znaczące jednostki polskiej kultury i polskiego języka, trudniej poddają się tłumaczeniom niż słowa czy zachowania pozbawione komponentu kulturowego, dlatego trzeba planować i prowokować zdarzenia pedagogiczne, w których nauczyciel i uczący się JPJO będą wspólnie interpretować polską przestrzeń kulturową (z zastosowaniem perspektywy porównawczej). 
- Kulturemy polskie nie są „własnością” jedynie Polaków. Żeby je wydobyć i właściwie zinterpretować potrzebne jest skrzyżowanie perspektyw (punktów widzenia) - spojrzenie na Polaków i świat Polaków oczami nie-Polaków i skonfrontowanie tych wyobrażeń i sądów z sądami „,swojaków", jak też z naszą własną, indywidualną opinią na dany temat. Każda „fałszywa”, odmienna lub niepełna interpretacja może zapoczątkować ważną rozmowę na temat wartości.

- Negocjowanie kulturemów - typowanie ich, interpretowanie - może się odbywać z użyciem metod opracowanych przez etnolingwistów (opisanych na przykładzie badań M. Raka) w połączniu z glottodydaktycznymi technikami stosowanymi $\mathrm{w}$ podejściu dyskursywnym (dialogicznym), interkulturowym, projektowym, zadaniowym i ludycznym.

- Zgodnie z podejściem dyskursywnym, efektywnemu uczeniu się języka sprzyja konfrontacja postaw i punktów widzenia.

- Podejście interkulturowe w nauczaniu języków obcych skupia się na wypracowywaniu w trakcie nauki języka obcego empatii i zainteresowania dla inności oraz poczucia, że dialog z innością spowoduje autorefleksję nad wartościami charakterystycznymi dla kultury rodzimej, jak też własny rozwój.

- Stosowanie w trakcie nauczania podejścia projektowego, zadaniowego i ludycznego powoduje przerwanie monotonii zajęć. Humor, dowcip, zadanie interaktywne, zespołowe dynamizują proces nauczania, sprzyjają lepszemu zaangażowaniu uczących się i dają im możliwość zaprezentowania i rozwijania kompetencji komunikacyjnych i społecznych.

\subsection{DOKONANIA GLOTTODYDAKTYKÓW POLONISTYCZNYCH W ZAKRESIE BADANIA POLSKICH FENOMENÓW KULTUROWYCH}

Ważna dyskusja na temat kultury w glottodydaktyce polonistycznej toczyła się w pierwszej dekadzie XXI wieku ${ }^{4}$. Jest także, choć z mniejszą intensywnością, kontynuowana także w kolejnym dziesięcioleciu. Jej efektem są propozycje programów kulturowego nauczania języka polskiego jako obcego, wykazy tematyczne znaczących elementów kultury i lingwakultury polskiej, lista egzotyzmów i haseł do planowanego słownika kultury polskiej dla cudzoziemców oraz prace poświęcone nauczaniu literatury (Czerkies 2012; Próchniak 2012) czy problemom

${ }^{4}$ Zob. prace o charakterze podsumowującym: A. Burzyńska (2002), Cudak R., Tambor J. (2002), Miodunka W. (2004); P. Garncarek (2006); P. Gębal (2010); J. Kowalewski (2011). Prace te zawierają bogatą literaturę przedmiotu. 
grzeczności polskiej (Żurek 2008, Rabczuk 2015, Sztabnicka-Gradowska 2017), jak też ukierunkowane kulturoznawczo glottodydaktyczne tomy wieloautorskie ${ }^{5}$.

Szczególnie wiele ciekawych artykułów związanych z poruszonym przez mnie zagadnieniem typowania kulturemów w nauczaniu języka polskiego jako obcego znalazło się w tomach warszawskich, będących pokłosiem polonistycznych konferencji organizowanych przez centrum Polonicum. Interesującym nas zagadnieniem zajęli się w swoich artykułach G. Rudziński (2010) i M. Skura (2010). Przedstawiony przez G. Rudzińskiego ranking fenomenów kulturowych został stworzony w wyniku negocjacji ze studentami specjalizacji glottodydaktycznej. Z przeprowadzonej przez autora analizy wynika, że respondenci - Polacy - są skłonni stawiać na pierwszym miejscu fenomeny kulturowe „z górnej półki" (reprezentujące kulturę wysoką - jak kategoria znaczących ludzi kultury czy dzieł literackich), gdy tymczasem, jak to wynika z innych badań, przedstawionych w tym samym tomie przez G. Zarzecznego i T. Piekota (2010) oczekiwania cudzoziemców są zupełnie inne ${ }^{6}$. Autorzy tej pracy sformułowali następujące wnioski z badań ankietowych: „Większości cudzoziemców najbardziej zależy na treściach kulturowych związanych z tzw. polską codziennością. [...] Koncepcje nauczania kultury nie są zatem dostosowane do opisu potrzeb oczekiwań cudzoziemców. [...] Naszym zdaniem tylko podejście interkulturowe zapewnia obu stronom bycie w zgodzie z samym sobą i jednocześnie rozumienie Innego. Wymaga to wprowadzenia do nauczania języka polskiego treści metakulturowych" (Zarzeczny, Piekot 2010, s. 206). Jak się wydaje, autorzy postulują pośrednio, by wszelkie rankingi fenomenów kulturowych czy treści podręczników były także konfrontowane z oczekiwaniami cudzoziemców uczących się polskiego. M. Skura, porównując w swoim artykule wybrane skrypty kulturowe polskie i niemieckie w zakresie zachowań grzecznościowych pokazuje, że znaczące miejsca kulturowe wymagające interpretacji na lekcji języka obcego można typować, stosując perspektywę porównawczą i koncentrując się szczególnie na socjokulturze. Inne pomysły na zapoznawanie cudzoziemców z polskimi kulturemami znajdujemy w pracach G. Zarzyckiej (2010, 2012) oraz I. Wieczorek (2016). Autorki uważają, że zanurzenie się w świat skrzydlatych słów (z zakresu kultury popularnej i wysokiej), nośnych kulturowo frazemów i nazw własnych - szczególnie tych, które mają także znaczenie wtórne - zapewni cudzoziemcom głębokie zanurzenie w kulturze języka docelowego.

${ }^{5}$ Zob. tomy pokonferencyjne: Garncarek P., Kajak P., Zieniewicz A. (2010), Garncarek P., Kajak P. (2012); Potasińska P., Stasieczek-Górna M. (2018). Ciekawe propozycje zajęć kulturowych (w tym lingwistycznokulturowych) znajdujemy w poszczególnych numerach „Kwartalnika Polonicum”. Szczególnie wiele wartościowych artykułów związanych z poruszonym przez mnie zagadnieniem typowania kulturemów (fenomenów kulturowych) w nauczaniu języka polskiego jako obcego znalazło się w tomie: Garncarek P., Kajak P., Zieniewicz A. (2010).

${ }^{6}$ Autorzy krytycznie przeanalizowali treści kulturowe podręczników do nauczania języka polskiego jako obcego, patrząc na nie oczami ich użytkowników - cudzoziemców. 
Problematykę związaną z kulturemami w obszarze kulinariów od kilku lat zgłębia J. Tambor, która kilkakrotnie wystąpiła z referatami na ten temat podczas dalekowschodnich „Spotkań Polonistyk Trzech Krajów: Chiny - Korea - Japonia" i opublikowała cykl artykułów na temat. Jej kolejne prace dotyczyły egzotyzmów kulinarnych w polszczyźnie (Tambor 2015), kulinarno-leksykanych przemian związanych z nazwami wybranych potraw (Tambor 2017) ${ }^{7}$ oraz zmian w zakresie „polskiego układu posiłków” (Tambor 2018, s. 205). Autorka wyciąga wnioski na podstawie analiz haseł słownikowych, jak też różnorodnych gatunkowo tekstów, jak fragmenty literatury pięknej, menu, książki i blogi kulinarne. Stosuje przy tym perspektywę interkulturową, dzięki czemu jej prace mają duży walor glottodydaktyczny. Wiele ciekawych analiz związanych z kulturemami, również kulinarnymi, w obszarze kultury słoweńskiej i języka słoweńskiego przedstawiły M. Wacławek i M. Wtorkowska (m.in. 2018)

\section{NEGOCJOWANIE TREŚCI KULTUROWYCH W PRAKTYCE GLOTTODYDAKTYCZNEJ - OPIS ZAJĘĆ WLASNYCH}

Obecnie zostaną opisane dwa zdarzenia dydaktyczne, których celem podstawowym było umotywowanie uczących się języka polskiego jako obcego, a także kandydatów na lektorów języka polskiego, do wydobywania, negocjowania i interpretowania polskich fenomenów kulturowych.

\subsection{SESJA KONWERSACYJNA PRZEPROWADZONA PRZEZ STUDENTKI Z CHORWACJI I SŁOWENII}

Poniżej przedstawiam przebieg sesji konwersacyjnej ${ }^{8}$ moderowanej przez dwie uczestniczki lektoratu języka polskiego na poz. średnio zaawansowanym, jaki prowadziłam w semestrze letnim 2017/2018 r. na Wydziale Filologicznym UŁ. Podstawą materiałową jest stenogram rozmowy sporządzony przeze mnie w czasie jej trwania.

Moderatorki dyskusji - Maja z Chorwacji i Katarzyna z Macedonii - wybrały następujący temat: różnice kulturowe w krajach słowiańskich reprezentowanych przez studentów $i$ wyktadowczynię: w Polsce, Ukrainie, oraz krajach batkańskich

\footnotetext{
${ }^{7} \mathrm{~W}$ tym artykule znajdujemy też opis koncepcji związanych z definiowaniem i rozumieniem kulturemu.

${ }^{8}$ Tego typu zdarzenia - sesje konwersacyjne prowadzone przez uczestników lektoratu na samodzielnie wybrany i wynegocjowany z kolegami z grupy studenckiej temat - to stały i sprawdzony punkt moich wszystkich zajęć na poz. zaawansowania co najmniej B1.
} 
- Chorwacji, Bułgarii $i$ w Macedonii. Jako ucząca w tej grupie byłam zaskoczona, że przedmiotem zainteresowania studentek stała się jedynie kultura życia codziennego, moderatorki nawet nie zagadnęly o kulturę wysoką. W trakcie trwającej ok. 45 minut rozmowy podjęto różnorodne tematy (w tekście podkreślono fragmenty, zaznaczając w ten sposób zmiany wątków w dyskusji).

\section{Podjęte problemy (tematy, postawione pytania):}

$* * *$

Moderatorki zaczęły od etykiety. Zwróciły się do Ukrainek z pytaniem, dlaczego gdy pani profesor zwraca się do kogoś z pytaniem, to one odpowiadaja wszystkie na raz. U nich w krajach jest to tępione. Ukrainki były zaskoczone pytaniem i nie potrafiły wyjaśnić swojego zachowania.

Moderatorki zapytały następnie, czy stosowane są na Ukrainie gesty: całowanie w dłoń i przepuszczanie kobiet $\mathrm{w}$ drzwiach przez mężczyzn. Ukrainki odpowiedziały, że pocałunek w dłoń to gest typowy tylko dla starszego pokolenia, natomiast drugie z zachowań jest powszechne.

Macedonka chciała wiedzieć, czy w Polsce obchodzi się hucznie imieniny. Z jej słów wynikało, że w jej kraju ludzie są bardzo towarzyscy i wszyscy członkowie jej rodziny w ten sposób to zdarzenie świętują. Odpowiedziałam, że w Polsce robiło tak starsze pokolenie, teraz zależy to od rodzin. Wzorzec kulturowy nie jest stały w naszym kraju. Młodsze pokolenie świętuje raczej urodziny.

Moderatorki zauważyły, że Polacy, gdy kończą wspólne posiedzenia w kawiarniach i restauracjach, bardzo skrupulatnie dzielą wspólny rachunek; nawet gdy jest to para, każdy płaci swoją część. Dopytywały o to, jakie są zwyczaje w krajach kolegów z grupy. Po uzyskaniu odpowiedzi dodały, że w krajach bałkańskich często się zdarza, że jedna osoba płaci za wszystkich, nie dbając o podział kosztów i zwrot pieniędzy. Przy kolejnej okazji płaci inna osoba.

Kolejnym wątkiem rozmowy stała się kwestia gościnności. Moderatorki zapytały, czy do polskiego i ukraińskiego domu można przyjść bez zapowiedzi. Stwierdziły: „Mieszkańcy Bałkanów są bardzo gościnni, u nas jest to normalne”. Odpowiedziałam, że kiedyś też tak w Polsce było, ale obecnie trzeba się zapowiedzieć; zwesternizowaliśmy się.

Jedno z pytań było skierowane bezpośrednio do mnie: czy bẹdạc gościem w polskim domu trzeba zdejmować buty? Powiedziałam, że u mnie w domu gość nie musi ich zdejmować (jeśli sam chce, podaję mu kapcie), ale znów, że w każdej rodzinie może być inaczej. Jak się okazało, na Bałkanach i na Ukrainie zawsze zmienia się obuwie po wejściu do mieszkania. Jedna z Ukrainek dopytywała, czy w takim razie domownicy chodzą w moim mieszkaniu w „butach z ulicy”. Odpowiedziałam, że nie, chodzimy w obuwiu domowym, w kapciach. Ukrainki i Macedonka oraz Chorwatka powiedziały, że one w akademiku też nie chodzą w „butach z ulicy”; ich goście, wchodząc do pokoju w domu studenta, też muszą zdjąć obuwie.

Macedonka zauważyła, że kiedy była na kursie w Katowicach, to w akademiku panował spokój, a w Łodzi zawsze jest głośno i bałagan. Ukrainki zapytane o sposób zachowania w domach studenckich na Ukrainie stwierdziły, że raczej cały tydzień sporo się w tych miejscach dzieje, podobnie jak w Łodzi. 
Maja (Chorwatka) usłyszała od polskiego chłopaka, że jego rodzice restrykcyjnie podchodza do tego, by w ich domu nocowała dziewczyna chłopaka. Chciała wiedzieć, czy to prawda, że w Polsce rodzice są bardzo konserwatywni i nie pozwalają nawet stałej dziewczynie czy stałemu chłopakowi dorosłych dzieci pozostawać na noc? Powiedziałam, że nie ma jednego wzorca kulturowego w Polsce w tej sprawie, ale że rodzice rzeczywiście mogą nie być chętni do udzielania noclegu partnerom (chłopakowi, dziewczynie) swoich dzieci, szczególnie tym niestałym.

Moderatorki zapytały, czy w Polsce można coś załatwić nielegalnie [podałam słówko: „na lewo"]? Odpowiedziałam, że w Polsce łapówkarstwo jest karane; np. nie jest przyjęte, ani możliwe, przekupywanie wykładowców. Prowadzące rozmowę wspomniały, że na Bałkanach korupcja, dawanie łapówek to duży problem. Podobnie, stwierdziły Ukrainki, jest w ich kraju. Ukrainki podały kwotę łapówki, która umożliwia skończenie jednego roku studiów.

Kolejnym tematem rozmowy stał się poziom uczelni wyższych. Maja zapytała, jakie są w Polsce wyższe szkoły prywatne? Dodała, że w Chorwacji uchodzą za złe, istnieje opinia, że nic się tam nie robi, a oceny można kupić. Ukrainki dodały, że tak samo dzieje się w ich kraju.

Maja zapytała o apteki: dlaczego jest ich w Polsce tak dużo? Widzi się je na każdym rogu. Wspomniałam o pędzie polskich farmaceutów po 1989 roku do zakładania własnych biznesów, a także o tym, że ten etap prosperity już się kończy - rynkiem farmaceutycznym zaczęły rządzić sieci, pojedyncze prywatne apteki upadają lub coraz trudniej jest się im utrzymać.

Temat przeniósł się na leki. Jedna z Ukrainek zapytała, które z nich można kupić bez recepty (bo u nich wszystkie). Wyjaśniłam, że te silne leki są na receptę, podobnie leki antykoncepcyjne i pigułki „dzień po”. Ten wątek zakończył rozmowę.

$* * *$

Podsumowując opisane zdarzenie dydaktyczne, wypada mi się zgodzić z obserwacjami G. Zarzecznego i T. Piekota (2010); uczestnicy przedstawionej dyskusji byli zainteresowani przede wszystkim kulturą życia codziennego: etykietą, relacjami międzyludzkimi (rówieśniczymi, międzypokoleniowymi), organizacją życia domowego (prywatnego, zawodowego; por. wątek gościnności, zakładania obuwia domowego), sprawami finansowymi (dzielenie się kosztami w restauracji), zdrowotnymi oraz ciemnymi stronami życia, jak łapówkarstwo. Rozmówczynie były zaciekawione zagadnieniami społecznymi, zachowaniami niewerbalnymi, mentalnością i charakterem narodowym Polaków oraz przedstawicieli krajów reprezentowanych przez uczestników dyskusji, skryptami kulturowymi, nie pojedynczymi leksemami, egzotyzmami językowymi. Oczywiście wynikiem tej rozmowy jest wyróżnienie szerszych kategorii tematycznych, w których można umieścić kulturemy leksykalne: DOM, EDUKACJA, ŻYCIE TOWARZYSKIE, ZDROWIE, FINANSE, RELACJE MIĘDZYLUDZKIE.

Rozmowa poprowadzona w duchu dialogu międzykulturowego (tak, by porównywać wzory kulturowe w różnych krajach), samodzielnie moderowana przez uczących się, pozwala zinterpretować trudne do zrozumienia zjawiska 
(skrypty) kulturowe, a rozmówcom daje możliwość konfrontacji wzorów kulturowych istniejących w Polsce z ich rodzimymi. Mogą oczywiście wystąpić duże różnice pokoleniowe między rozmówcami (np. studentki z Ukrainy zwykle nie miały jeszcze 18 lat, moderatorki miały po 22 lata, a jedna ze studentek - Bułgarka, doktorantka, miała 38 lat). Wtedy rozmowa jest jeszcze ciekawsza i bardziej burzliwa.

Moja główna refleksja towarzysząca tej rozmowie była następująca: Pozwólmy uczącym się języka polskiego jako obcego prowadzić dyskurs o kulturze według ich własnych reguł. Wtedy jest szansa na to, by dowiedzieć się o nich i o sobie czegoś, czego się może nie spodziewaliśmy9.

\subsection{QUIZ NA POLSKOŚĆ}

W opisanych poniżej zdarzeniach krzyżowane są punkty widzenia rodzimych użytkowników (kandydatów na lektorów języka polskiego jako obcego) oraz cudzoziemców (uczestników lektoratu języka polskiego na poz. średnio zaawansowanym) na fenomeny polskiej kultury. Punktem wyjścia do negocjacji stała się lista kulturemów polskich wytypowanych przez cudzoziemkę - Laurę Klos Sokol (2015), Amerykankę mieszkającą w Polsce - i zaprezentowana obu stronom w postaci humorystycznego quizu.

\subsubsection{KROK PIERWSZY - zajęcia ze studentami polskimi na specjalizacji „Nauczanie języka polskiego jako obcego” UŁ}

Przetłumaczyłam quiz na język polski i poprosiłam studentów o rozwiązanie go. Następnie zostały przedyskutowane te punkty, które zdaniem studentów (należeli do pokolenia dwudziestolatków) nie były do końca reprezentatywne dla ich pojmowania polskości (część także dla mnie - np. nie wiedziałam, co to za drink: szarlotka; zob. quiz, p. 22). Zostali także poproszeni o dopisanie kolejnych punktów do quizu, dopełniając w ten sposób listę fenomenów kulturowych zaproponowanych przez cudzoziemkę. Mogli też wykreślić niektóre punkty.

${ }^{9} \mathrm{Z}$ moich doświadczeń wynika, że bardzo ciekawe rezultaty w zakresie dyskursywnego wydobywania kulturemów może przynieść rozmowa o zderzeniach kulturowych. 


\section{QUIZ NA POLSKOŚĆ}

(na podstawie: Sokol 2015, s. 7-9; tłum. G. Z.)

\section{JAK BARDZO JESTEŚ POLAKIEM/POLKĄ? CZY TYLKO ODROBINĘ? A MOŻE JESTEŚ BARDZIEJ POLSKI/POLSKA NIŻ POLACY? ROZWIĄŻ TEN QUIZ I ODKRYJ SWÓJ POZIOM POLSKOŚCI.}

1. Czy w ostatnich sześciu miesiącach spędziłeś/spędzilaś ponad 3 godziny na siedzeniu przy stole i jedzeniu oraz piciu?

Przyznaj sobie 3 p. za TAK; 0 p. za NIE.

2. Lubisz Prince Polo lub Ptasie Mleczko?

1 p. za każe TAK; 0 p. za każde NIE; -1 p. za każdą opcję, jeśli w ogóle nie wiesz, o czym się tu mówi.

3. Czy podczas Świąt Bożego Narodzenia lub Nowego Roku składasz życzenia każdej osobie z osobna?

1 p. za TAK; 0 p. za: NIE, składam jedynie ogólne życzenia, takie jak: Wesołych Świąt!

i Szczęśliwego Nowego Roku!

4. Czy uczestniczyłeś/uczestniczyłaś kiedykolwiek w parapetówce - imprezie z okazji otrzymania lub zakupu nowego mieszkania - w którym nie było żadnych mebli?

2 p. za TAK; 1 p. za: TAK, ale mieszkanie było umeblowane; 0 p. za NIE; -1 p., jeśli dotąd nie otrzymałeś/otrzymałaś zaproszenia na parapetówkę.

5. Czy byłeś/byłaś u kogoś na działce?

1 p. za TAK; dodaj 1 p., jeśli sam/sama jesteś właścicielem działki; 0 p. za NIE.

6. Lubisz tatara (befsztyk tatarski)?

1 p. za TAK; 2 p., jeśli: TAK, szczególnie, gdy popijam go kieliszkiem wódki; 0 p. za NIE;

-1 p., jeśli nie wiesz, co to takiego.

7. Czy, kiedy wybierasz się z wizytą do przyjaciela, czujesz się nieswojo, jeśli przychodzisz z pustymi rękoma?

$$
1 \text { p. za TAK, } 0 \text { p. za NIE. }
$$

8. Czy zwykle na powitanie lub pożegnanie ściskasz każdej osobie rękę lub całujesz zamiast zawołać do całej grupy: cześć! hej! lub: do widzenia?

$$
1 \text { p. za TAK, } 0 \text { p. za NIE. }
$$

9. Czy jadłeś/jadłaś kiedykolwiek śledzia w occie? Wędzonego węgorza? Karpia? Przyznaj sobie 1 p. za każdą z tych ryb; 0 p., jeśli nie jadłeś żadnej z wymienionych.

10. Czy Twój krewny gościl kiedyś w Twoim domu dłużej niż 2 tygodnie?

$$
2 \text { p. za TAK; } 0 \text { p. za NIE. }
$$

11. Czy kiedykolwiek spałeś/spałaś przez dłuższy czas na rozkładanej wersalce lub rozkładanym lóżku?

2 p. za TAK; dodaj sobie 1 p., jeśli rozkładasz i składasz swoją wersalkę / swoje łóżko codziennie; 0 p. za NIE; -1, jeśli nie ma takiego mebla w Twoim domu/mieszkaniu. 
12. Czy Twoje nazwisko składa się z 3 lub więcej sylab lub, przynajmniej, jest w nim trzy razy więcej spółgłosek niż samogłosek?

1 p. za TAK; 0 p. za NIE.

13. Czy, kiedy siedzisz wieczorem przy stole z przyjaciółmi, ktoś co jakiś czas wznosi toast?

$$
1 \text { p. za TAK; } 0 \text { p. za NIE. }
$$

14. Czy często spacerujesz po parku w niedzielne popołudnie?

1p. za TAK; dodaj 1 p. jeśli ubierasz się wtedy elegancko; 0 p. za NIE.

15. Czy masz w domu dodatkowe kapcie (domowe obuwie) dla gości?

$$
3 \text { p. za TAK; } 0 \text { za NIE. }
$$

16. Czy zabierasz własne kapcie, kiedy wybierasz się z wizytą do domu przyjaciól?

$$
3 \text { p. za TAK; } 0 \text { za NIE. }
$$

17. Czy zwykle chodzisz do kościoła w niedziele i święta?

$$
1 \text { p. za TAK; } 0 \text { za NIE }
$$

18. Czy masz wyrobioną opinię na temat smaku bigosu?

2 p. za TAK; 0 za NIE; -1, jeśli nigdy nie jadłeś/jadłaś domowego bigosu.

19. Czy wypiłbyś/wypiłabyś coś zimnego lub zjadłbyś/zjadłabyś lody, gdybyś mial/miała zapalenie gardla?

2 p. za NIE; dodaj 1 p., jeśli przestrzegłbyś/przestrzegłabyś kogoś przed zrobieniem tego; -1 p. za TAK.

20. Czy, gdy do twojego domu przychodzą goście, natychmiast proponujesz im coś do picia?

$$
2 \text { p. za TAK; } 0 \text { p. za NIE. }
$$

21. Czy miałeś/miałaś kiedykolwiek 12 gości w mieszkaniu nie większym niż 40 m²$^{2}$ ?

3 p. za TAK; dodaj 1 p. jeśli było u Ciebie więcej niż 16 gości; 0 p. za NIE;

-1 p., jeśli nigdy nieprzyjmowałeś/przyjmowałaś w domu gości lub jeśli zawsze mieszkałeś/mieszkałaś

w większym mieszkaniu.

22. Czy znasz składniki drinka o nazwie szarlotka?

2 p. za TAK; 0 p. za NIE.

23. Czy kiedykolwiek przyrządzałeś/przyrządzałaś kawę, sypiąc zmielone ziarna kawy do szklanki (kubka) i zalewając je wrzątkiem (gorącą wodą)?

3 p. za TAK; 0 za NIE; -2 p., jeśli nigdy nie widziałeś/widziałaś, by ktoś to robił.

24. Czy znasz caly tekst piosenki Sto lat?

$$
\text { 25. } 2 \text { p. za TAK; -1 za NIE. }
$$

\section{PUNKTACJA:}

- 46 punktów lub więcej: Gratulacje! Jesteś nadzwyczajnie polski/polska. Może nawet bardziej polski/polska niż Polacy.

- 24 do 45 punktów: Jesteś bardzo polski/polska. Proszę, sprawdź paszport!

- 11 do 23 punktów: Już jesteś co nieco polski/polska. Tak trzymaj, masz wielki potencjał!

- 1 do 10 punktów: Jesteś Polakiem/Polką w negatywie. Może to znaczyć, że dopiero zaczynasz swoją wyprawę. Nie przejmuj się, niedługo pozbędziesz się swojej cudzoziemskości. Jednak, może to również znaczyć, że jesteś godny/godna pożałowania. Bądź bardziej wytrwały/wytrwała! 


\section{Przykłady uzupełnień zaproponowanych przez polskich studentów:}

Czy kiedykolwiek nosiłeś skarpety do sandałów na plaży?; Czy kiedykolwiek jadłeś kiszone ogórki lub kiełbasę? Czy znasz disco polo? / Czy znasz Zenka Martyniuka?; Czy twój obiad w niedzielę składa się zawsze z dwóch dań? / Czy następnego dnia z rosołu robisz zupę pomidorową? ${ }^{10}$; Czy jednym z twoich codziennych posiłków są kanapki?; Czy narzekasz chociaż raz w ciągu dnia?; Czy często rozmawiasz o polityce?; Czy jechałeś kiedykolwiek maluchem?/W ile osób?; Czy jadłeś chleb ze smalcem i ogórkiem? / Czy wiesz, jak zrobić smalec?; Czy kiedykolwiek jadłeś pierogi? / Czy wiesz, jak się je robi? / Czy je robiłeś?; Czy oglądasz skoki narciarskie? ${ }^{11}$; Czy wiesz, co to jest domówka? / Czy byłeś na jakiejś? / Czy sam taką organizowałeś?; Czy nazwiska Kochanowski, Mickiewicz, Słowacki cokolwiek Ci mówią?; Czy znasz chociaż 3 rodzaje przygotowania ogórków? (konserwowe, kiszone, małosolne)?; Czy znasz toruńskie pierniki?; Czy lubisz mizerię?; Czy chodzisz do dziadków na niedzielne obiady?; Czy klaszczesz po wylądowaniu samolotu?; Czy wiesz, co to jest ,rozchodnik”?; Czy jadłeś kogel-mogel? Czy wiesz, jak go zrobić?; Czy znana jest Ci postać Ferdynada Kiepskiego?; Czy na święta podajesz rosół?; Czy lubisz kisiel?; Czy na Wszystkich Świętych stawiasz chryzantemy na grobach?; Czy w Wigilię jesz zawsze karpia?; Czy po wizycie u mamy lub babci przywozisz domowe jedzenie w słoikach?

Analizując zawartość quizu zaproponowanego przez L. Klos-Sokol zauważamy, że leksyka kulturowa wskazana przez nią mieści się w takich kategoriach semantycznych, jak: zachowania społeczne (w tym przede wszystkim etykieta, polskie zwyczaje, zachowania niewerbalne), nazwy specyficznych polskich produktów i kulinariów. Wśród pytań sformułowanych przez polskich studentów najwięcej jest związanych ze zwyczajami odświętnymi oraz codziennymi (szczególne miejsce zajmuje tu kultura biesiadna, w tym kulinaria i polskie „śmiesznostki” i dziwactwa), kulturą popularną. Utworzenie nowej listy polskich fenomenów kulturowych jest oczywiście jedynie wstępem do kolejnej negocjacji znaczeń kulturowych, gdyż pytania wymagają, jeśli przyjąć wzorzec z quizu L. Klos-Sokol, dopisania odpowiednio wymodelowanych odpowiedzi i punktacji.

${ }^{10} \mathrm{O}$ takim zwyczaju kulinarnym informuje R. Sikorski w wywiadzie z Magazynu Świątecznego „Gazety Wyborczej”, 26-27 V 2018. Rosół, a drugiego dnia pomidorówkę, gotuje za każdym razem jego żona Anne Applebaum, Amerykanka, która zachwyciła się polską kuchnią i napisała przewodnik po polskiej kuchni dla Amerykanów.

${ }^{11}$ Zob. wywiad Ewy Furtak z Apoloniuszem Tajnerem: Skoki narciarskie pasują do polskiego charakteru, Magazyn „Gazety Wyborczej”, 18 września 2018. 


\subsubsection{KROK DRUGI}

Powyższy quiz wykorzystałam także w grupie cudzoziemskiej - słowiańskiej. Wyniki testu na podobieństwo z Polakami były następujące: $50 \%$ studentów uzyskało od 24 do 45 p.; 40\% - od 11 do 23 p.; 10\% (1 osoba) okazała się „Polką w negatywie". Nie wszystkie zachowania były zrozumiałe, trzeba było je objaśnić. Okazuje się, że pokrewieństwo słowiańskie nie niweluje wszystkich różnic.

\section{PODSUMOWANIE}

W końcowym fragmencie pracy pragnę się skupić na ocenie efektu pedagogicznego i kulturowego zaproponowanego zadania.

W przypadku studentów polskich ważnym efektem było skłonienie ich do refleksji na temat naszych cech narodowych, czyli „kulturowych uniwersaliów polskich". Wykonując quiz zaproponowany przez Amerykankę, zastanawiali się jednocześnie, do jakiego stopnia owe wyróżnione przez nią wartości są wspólne dla Polaków jako przedstawicieli jednej grupy narodowej czy składających się na nią grup pokoleniowych i regionalnych. Istotne okazało się zwrócenie uwagi na fakt, że owe wartości kulturowe zostały wytypowane przez cudzoziemkę. Porównanie autostereotypu $\mathrm{z}$ heterostereotypem jest zawsze niezwykle cenne i w przypadku przedstawicieli grupy, do której odnoszą się dane stwierdzenia, prowadzi do zobiektywizowania opinii o cechach własnej zbiorowości. Część studentów będzie w przyszłości nauczać języka polskiego jako obcego i wykorzysta tę lekką, dyskursywną, quizową formę do porównywania wzorów kulturowych oraz do przekazywania i negocjowania informacji kulturowych. Myślę, że studenci polscy biorący udział w opisanym wydarzeniu zostali jednocześnie uwrażliwieni na to, że warto wsłuchiwać się w głosy Innych opisujących naszą kulturę.

Istotnym rezultatem zadania dydaktycznego przeprowadzonego w środowisku studentów zagranicznych było dostarczenie uczącym się impulsu skłaniającego do rozmowy o własnych doświadczeniach w Polsce. Mieli oni okazję ocenić, czy ich obserwacje odnoszące się do polskiej kultury i zachowań Polaków pokrywają się z opisem przedstawionym przez autorkę quizu. Efektem rozmowy poprowadzonej po wypełnieniu quizu była próba odpowiedzi na pytanie, do jakiego stopnia jesteśmy podobni lub różni? Quiz posłużył także wzbogaceniu zasobu leksykalnego uczących się języka polskiego jako obcego o ważne jednostki leksykalne zawierające komponent kulturowy. Gdy w grupie uczących się języka polskiego jako obcego znajdą się osoby zainteresowane tematem, można polecić im wykonanie zadania polegającego na stworzeniu podobnego quizu, w którym 
spróbują przedstawić fenomeny charakterystyczne dla ich kultury rodzimej ${ }^{12}$. Przedstawiając taki quiz kolegom z grupy, skłonią ich do zapoznania się z ich kulturą, co w efekcie spowoduje wzrost u wszystkich stron wrażliwości i kompetencji kulturowej, a także kompetencji komunikacyjnych ${ }^{13}$. Przeprowadzone zajęcia mogą też dostarczyć impulsu do wykonania zadania polegającego na opisie, $\mathrm{w}$ formie ustnej lub pisemnej, zderzeń kulturowych.

$* * *$

Przedstawione powyżej sposoby aplikacji do glottodydaktyki polonistycznej metodologii i rezultatów badań o charakterze etnolingwistycznym pokazują, że owo przełożenie może dostarczyć wartościowych danych również do dalszych badań nad uwarunkowaniami komunikacji interkulturowej, mentalnością przedstawicieli różnych grup narodowych, stereotypami i ich funkcją społeczną.

\section{BIBLIOGRAFIA}

Agar M., 1994, Language Shock. Understanding the Culture of Conversation, New York.

Bartmiński J., 1988, Definicja kognitywna jako narzędzie opisu konotacji słowa, w: Konotacja, J. Bartmiński (red.), Lublin, s. 169-183.

Bartmiński J., 2007, Stereotypy mieszkają w języku. Studia etnolingwistyczne, Lublin.

Burkhardt H., 2008, Kulturemy $i$ ich miejsce $w$ teorii przekladu, „Język a Kultura”, t. 20, s. $197-211$.

Burzyńska A., 2002, „Jakże rad bym się nauczyt polskiej mowy...” O glottodydaktycznych aspektach relacji ,język a kultura" w nauczaniu języka polskiego jako obcego, Wrocław.

Cudak R., Tambor J. (red.), 2002, Kultura polska. Silva rerum, Katowice.

Czerkies T., 2012, Tekst literacki w nauczaniu języka polskiego jako obcego (z elementami pedagogiki dyskursywnej), Kraków.

Dąbrowska A., Współczesne problemy lingwistyki kulturowej, http://filologia-polska.pwa.edu.pl [15.09.2018].

Fleischer M., 2003, Polska symbolika kolektywna, Wrocław.

Galisson R., 1999, La pragmatique lexiculturelle pour accédar autrement, à une autre culture, par un autre lexique, „Études de Linguistique Appliquée” (ÉLA), nr 116, s. 477-496.

Garncarek P., 2006, Przestrzeń kulturowa w nauczaniu języka polskiego jako obcego, Warszawa.

Garncarek P., Kajak P. (red.), 2012, Kultura popularna w nauczaniu języka polskiego jako obcego, Warszawa.

Garncarek P., Kajak P., Zieniewicz A. (red.), 2010, Kanon kultury w nauczaniu języka polskiego jako obcego, Warszawa.

Gębal P., 2010, Dydaktyka kultury polskiej w ksztatceniu językowym cudzoziemców, Kraków.

${ }^{12}$ L. Klos-Sokol w zakończeniu książki Shortcuts to Poland proponuje także „quiz na amerykańskość".

${ }^{13}$ Bardzo ciekawe quizy oparte na wzorcu przedstawionym przez L. Klos-Sokol, świetnie opisujące zachowania kulturowe swoich rodaków, przygotowali na lektoracie językowym, który prowadziłam na Wydziale Filologicznym UŁ w semestrze letnim 2018/2019 r., student z Tajpej oraz studentka z Bułgarii. To zdarzenie dydaktyczne przeanalizuję w innej pracy. 
Klos Sokol L., 2015, Shortcuts to Poland, wyd. 4, Warszawa 2015.

Kowalewski J., 2011, Kultura polska jako obca?, Kraków.

Ligara B., 2009, Perspektywa kulturoznawcza nauczania kodu: teoria leksykultury Roberta Galissona, w: W. Miodunka (red.), Nowa generacja w glottodydaktyce polonistycznej, Kraków, s. $119-145$.

Łaziński M., Słowa klucze prasy polskiej. Słowa dnia i słowa roku UW, http://www.slowanaczasie. uw.edu.pl/wp-content/uploads/klucze.pdf [15.10.2018].

Miodunka W. (red.), 2004, Kultura w nauczaniu języka polskiego jako obcego. Stan obecny - programy nauczania - perspektywy, Kraków.

Nagórko A., 1994, Z problemów etnolingwistyki - jak porównywać języki i kultury, „Poradnik Językowy", nr 4, s. 4-14.

Nagórko A., 2004, Metody konfrontatywne a etnolingwistyka (lingwistyka kulturowa), w: E. Forian (red.), Wielokulturowość, tożsamość, mniejszości na Węgrzech $i$ w Polsce. Język - literatura - kultura, Debreczyn, s. 25-33.

Oksaar E., 1998, Kulturentheorie, „Berichte aus den Sitzungen der Joachim-Jungius-Gesellschaft der Wissenschaften", e.V, Jg.6, H.3. Göttingen, s. 26-49.

Pisarek W., 2003, Polskie słowa sztandarowe i ich publiczność, Kraków.

Potasińska P., Stasieczek-Górna M. (red.), 2018, Wyzwania glottodydaktyki polonistycznej. „Życie zaczyna się po sześćdziesiątce”, Warszawa.

Próchniak W., 2012, Klucz do wierszy. Poezja w nauczaniu języka polskiego jako obcego, Lublin.

Przybylska R., 2005, Projekt stownika egzotyzmów polskich dla cudzoziemców, w: P. Garncarek (red.), Nauczanie języka polskiego jako obcego i polskiej kultury w nowej rzeczywistości europejskiej, Warszawa, s. 290-294.

Rabczuk A., 2015, Jak całować polskim kobietom ręce, w: I. Bundza, A. Krawczuk, J. Kowalewski J., O. Slivinskij (red.), Język polski i polonistyka w Europie Wschodniej: przeszłość i wspótczesność, Kijów 2015, s. 499-514.

Rak M., 2015, Kulturemy podhalańskie, Kraków 2015. https://ruj.uj.edu.pl/xmlui/bitstream/handle/ item/15647/rak kulturemy podhalanskie.pdf?sequence=1\&isAllowed=y [15.09.2018].

Rudziński G., 2010, Rankingi fenomenów polskiej kultury autorstwa studentów specjalizacji Nauczanie Języka Polskiego jako Obcego, w: P. Garncarek, P. Kajak, A. Zieniewicz (red.), 2010, Kanon kultury w nauczaniu języka polskiego jako obcego, Warszawa, s. 207-214.

Skura M., 2010, Przykłady kulturemów w językach polskim i niemieckim, P. Garncarek, P. Kajak, A. Zieniewicz (red.), 2010, Kanon kultury w nauczaniu języka polskiego jako obcego, Warszawa, s. 175-180.

Sztabnicka-Gradowska E., 2017, Model polskiej grzeczności językowej w nauczaniu języka polskiego jako obcego. Perspektywa interkulturowa, Łódź, http://dspace.uni.lodz.pl:8080/xmlui/ handle/11089/22939 [15.09.2018].

Tambor J., 2008, Mowa Górnoślazaków, Katowice.

Tambor J., 2015, Egzotyzmy kulinarne w i na języku Polaków. Rozważania o jedzeniu, mówieniu i pisaniu, w: Koji Morita (red.), „Spotkania Polonistyk Trzech Krajów - Chiny, Korea, Japonia - Rocznik 2014/2015", Tokio, s. 83-92.

Tambor J., 2017, Polskie kulinarno-leksykalne przemiany: czy Polacy wiedza, co jedza?, Mao Inhui (red.), „Spotkania Polonistyk Trzech Krajów - Chiny, Korea, Japonia - Rocznik 2016/2017”, Kanton-Warszawa, s. 315-332.

Tambor J., 2018, Pierwsze, drugie i... co dalej? Kolejność dań na polskim stole, w: Yongdeog Kim (red.), ,Spotkania Polonistyk Trzech Krajów - Chiny, Korea, Japonia - Rocznik 2018/2019”, Seul, s. 203-212.

Wacławek M., Wtorkowska M., 2018, Powiedz mi, co jesz, a powiem ci, kim jesteś - o kulinariach w Słowenii, „Acta Universitatis Lodziensis. Kształcenie Polonistyczne Cudzoziemców”, t. 25, s. $55-68$.

Wieczorek I., 2016, Strachy na Lachy. Nazewnicze komponenty przystów i frazeologizmów. Opracowanie do nauki języka polskiego jako obcego. Poziom zaawansowany, Poznań. 
Wierzbicka A., 1999, Emocje, Język $i$,skrypty kulturowe”, w: A. Wierzbicka, Język-umyst-kultura, Warszawa, s. 163-189.

Wierzbicka A., 2007, Stowa klucze. Różne języki - różne kultury, Warszawa.

Zarzeczny G., Piekot T., 2010, Inny punkt widzenia - treści kulturowe w podręcznikach oczami cudzoziemców, w: P. Garncarek, P. Kajak, A. Zieniewicz (red.), 2010, Kanon kultury w nauczaniu języka polskiego jako obcego, Warszawa, s. 199-206.

Zarzycka G., 2004, Lingwakultura - czym jest, jak ja badać i „otwierać”, w: A. Dąbrowska (red.), Wroctawska dyskusja o języku polskim jako obcym, Wrocław, s. 435-444.

Zarzycka G, 2008, Kultura, lingwakultura, socjokultura w nauczaniu języka polskiego jako obcego, w: A. Seretny, E. Lipińska (red.), Rozwijanie i testowanie biegłości w języku polskim jako obcym, Kraków, s. 143-160.

Zarzycka G., 2010, Skrzydlate słowa w procesie nauczania języka polskiego jako obcego. Propozycje programowe, w: P. Garncarek, P. Kajak, A. Zieniewicz (red.), 2010, Kanon kultury w nauczaniu języka polskiego jako obcego, Warszawa, s. 121-142.

Zarzycka G., 2012, Kultura popularna w polskich skrzydlatych stowach, w: P. Garncarek, P. Kajak (red.), Kultura popularna w nauczaniu języka polskiego jako obcego, Warszawa.

Żurek A., 2008, Grzeczność językowa w polszczyźnie cudzoziemców, Łask.

Grażyna Zarzycka

\section{POLISH CULTUREMES - POINTS OF VIEW, TECHNIQUES FOR THEIR SELECTION AND NEGOTIATION. APPLYING ETHNOLINGUISTIC PERSPECTIVE IN POLISH LANGUAGE GLOTTODIDACTICS}

Keywords: cultureme, points of view, selection, nomination, negotiation, ethnolinguistics, Polish-language glottodidactics, teaching Polish as a foreign language

Abstract. The article calls for the application of ethnolinguistic methodology in Polish-language glottodidactics. In the introductory part, the concept of cultureme - a cultural unit belonging to a given cultural system and relevant to its understanding - is discussed with the use of world and Polish literature on the subject. The necessity to include culture in teaching Polish as a foreign language is an undisputed matter. Ways of selecting culturemes from the vast space of culture specific unites seem to be less obvious. Who is ,,authorized" to nominate them - only a representative of the native culture or, also, an external observer? Can culturemes be selected as a result of the negotiation process? The article presents the techniques for their selection and negotiation using internal and external perspectives, as well as proposals to use this methodology in the practice of teaching Polish as a foreign language. 